\title{
Effect of Culture Media on Mare Oocytes Maturation
}

\author{
Hussam ARYAN*, Ioan GROZA, Iancu MORAR, Liviu BOGDAN, Anamaria PETREAN, Omar MARDENLI \\ ${ }^{1}$ Department of Veterinary Obstetrics, Gynecology and Reproduction, University of Agricultural Sciences \\ and Veterinary Medicine Cluj-Napoca, Romania, \\ *Corresponding author: hussamaryan@yahoo.com
}

Bulletin UASVM Veterinary Medicine 73(1) / 2016,

Print ISSN 1843-5270; Electronic ISSN 1843-5378

DOI:10.15835/buasvmcn-vm: 11610

\begin{abstract}
432 mare oocytes were collected from ovaries of slaughtered animals and cultured in three mediums supplimented with hormons (FSH, LH) and nutritive substances and were cultivated for 24 hours in three media, the highest cultivation rate in three media was obatined in TCM-199 medium 53.33\% (80 oocytes), followed by SOF medium, maturation rate was $39.65 \%$ (58 oocytes), but the less maturation rate $(34.54 \%$ ) was observed in the medium composed of TCM $+5 \%$ SOF $+5 \%$ FCS $+1 \%$ glutamine $+1 \%$ A.A $+500 \mu$ l antibiotic). Oocytes were selected and classified in two quality categories (mature, degenerated).
\end{abstract}

Keyword: Degenerated, maturation, medium, oocyte, recovery.

\section{INTRODUCTION}

Oocytes recovery and cultivation media were selected according to the species, stage of follicular development, recovery tehnique and storage duration (Groza et al., 2004). Cultivation systems were diversified rapidly, based on consecrate elements, besides ensuring their supplements (hormones, vitamins, protein) as increasing the potential for development after fertilization. These supplements are: epidermal growth factor, growth hormone, bovine serum albumin (BSA), synthetic oviduct fluid (SOF) etc. (Squires, 2005). We believe that mare oocytes in vitro fertilization protocol, ensuring complete maturation by cultivation in different complex mediums are key points for the success of this biotechnology.

The aim of this paper is to evaluate media and solutions used in oocyte maturation for improving their original contributions and correlation morphological study with the degree of maturation and selection for fertilization.

\section{MATERIAL AND METHOD}

Research was conducted on a number of 432 mare oocytes collected from ovaries of slaughtered animals in abattoir Cetina (Baia Mare), Romania. After examining on the stereo- and inverted microscope, recovered oocytes were identified, selected and classified into two quality categories based on morphological characteristics. Only cultivable oocytes were used for in vitro maturation due to their ability to continue their development and precurge „, in vitro” fertilization (Fig. 1).

Before being transferred to the maturation medium, selected oocytes were subjected to the washing process in medium collection by repeatedly aspiration (three times). Last pass was done in the maturation medium to remove impurities and to avoid contamination. Selection of media used for maturation was performed bearing in mind necessities of protein, vitamins and hormones to initiate and ensure the development potential of mare oocytes to metaphase II of meiotic division (appearance first polar body).

Using a fine pipette with a diameter of $50 \mu$, 5-6 oocytes were placed in medium. The prepared plates were introduced to the incubator for 24 hours at a temperature $38.2-38.5 \circ \mathrm{C}$ and $5.3 \% \mathrm{CO}_{2}$. Depending on the morphological caracteristics 
observed after cultivation for 24 hours and stereoand inverted microscope examination.

\section{RESULTS AND DISCUSSION}

Mare oocyte in vitro cultivation which was performed in medium for 24 hours in three culture medium supplemented originally, aimed for completion of maturation and preparation for in vitro fertilization protocol. 432 mare oocytes were cultured. Cultivation process in three culture media as follows :

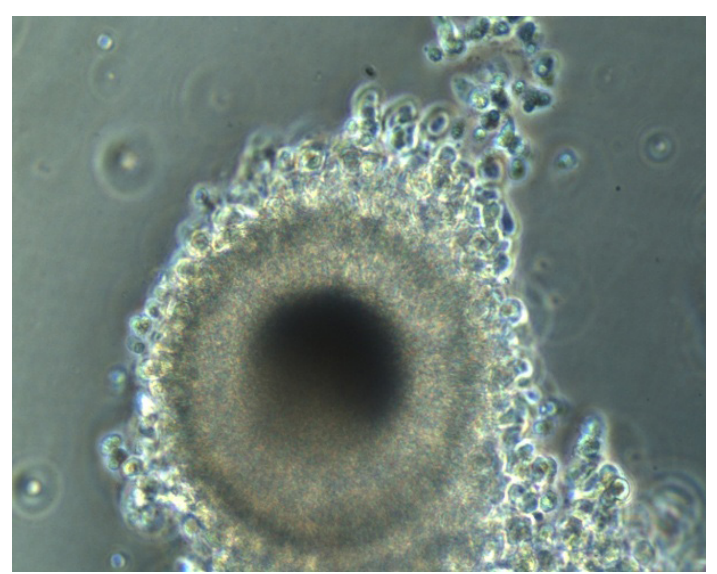

150 oocytes were cultured in medium TCM -199 supplemented with $10 \%$ FCS + 25 mM HEPES $+1 \mathrm{mM}$ sodium pyruvate $+1 \%$ glutamine + $1 \% \mathrm{AA}+10 \mu \mathrm{g} / \mathrm{ml}$ of FSH $+2 \mu \mathrm{g} / \mathrm{ml}$ of $\mathrm{LH}+500$ ul antibiotic;

137 oocytes were cultured in medium consisting of TCM -199 supplemented with $5 \%$ SOF $+5 \% \mathrm{FCS}+1 \%$ glutamine $+1 \% \mathrm{AA}+500 \mathrm{ul}$ antibiotic;

145 oocytes were cultured in medium consisting of SOF supplemented with $10 \%$ FCS + $1 \%$ glutamine $+1 \% \mathrm{AA}+500 \mathrm{ul}$ antibiotic .

Fig. 1 Recoverd oocytes used for in vitro maturation

Tab.1 Composition of media used for mare oocyte in vitro maturation

\begin{tabular}{cc}
\hline Media & Composition \\
\hline TCM-199 & $\begin{array}{c}\text { TCM-199 }+10 \% \text { FCS }+25 \mathrm{mM} \text { HEPES }+1 \mathrm{mM} \text { sodium Piruvate }+1 \% \\
\text { glutamine }+1 \% \mathrm{~A} . \mathrm{A}+10 \mu \mathrm{g} / \mathrm{ml} \mathrm{FSH}+2 \mu \mathrm{g} / \mathrm{ml} \text { LH }+500 \mu \mathrm{l} \text { antibiotic }\end{array}$ \\
\hline SOF & SOF $+10 \%$ FCS $+1 \%$ glutamine $+1 \% \mathrm{~A} \cdot \mathrm{A}+500 \mu \mathrm{l}$ antibiotic \\
\hline TCM + SOF & TCM $+5 \%$ SOF $+5 \%$ FCS $+1 \%$ glutamine $+1 \%$ A.A $+500 \mu l$ antibiotic \\
\hline
\end{tabular}

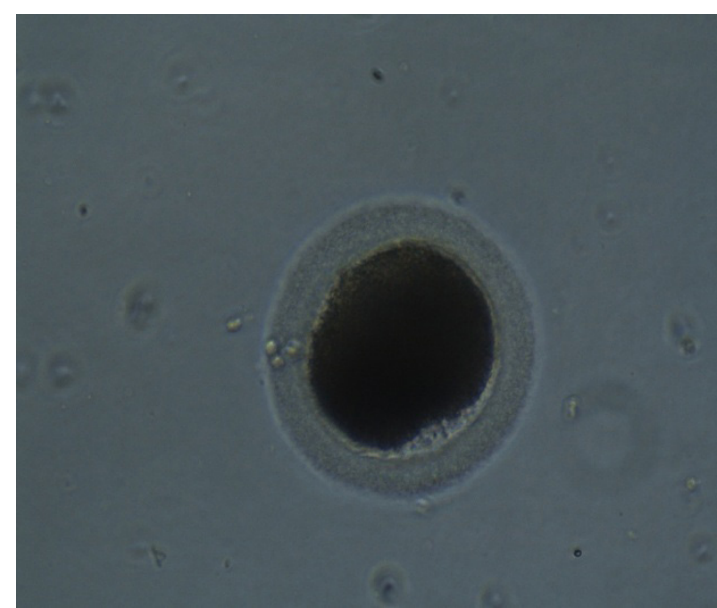

Fig. 2 Mature Oocyte

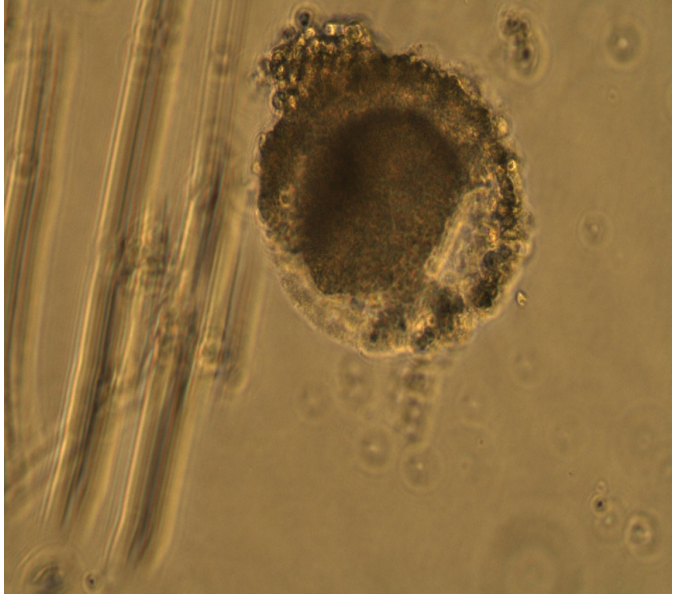

Fig. 3 Degenerated Oocyte 
After stereo- and inverted microscope examination, mare oocytes were classified into two quality categories:

Mature oocytes: presenting expanded cumulus to five layers of cellule around the oocyte, the presence of the first polar body, homogeneous cytoplasm, integrity pellucida membrane and uniform space perivitelin;

Degenerate oocytes: presenting unexpanded cumulus or partial denudation, granular cytoplasm, retracted and space perivitelin ununiform.

The obtained results after mare oocytes in vitro cultivation and classification of quality are presented in the following table (Table 2):

Comparing results of maturation for $24 \mathrm{~h}$ in three media, it highlights those obtained in TCM-199 medium supplemented with 10\% FCS $+25 \mathrm{mM}$ HEPES $+1 \mathrm{mM}$ sodium pyruvate $+1 \%$ glutamine $+1 \% \mathrm{AA}+10 \mu \mathrm{g} / \mathrm{ml} \mathrm{FSH}+2 \mu \mathrm{g} / \mathrm{ml} \mathrm{LH}$ $+500 \mu \mathrm{l}$ antibiotic, where the maturation rate was $53.33 \%$ (80 oocytes), followed by SOF medium supplemented with $10 \%$ FCS + 1\% glutamine + $1 \% \mathrm{AA}+500 \mu \mathrm{l}$ antibiotic, maturation rate was $39.65 \%$ (58 oocytes), but the less maturation rate $34.54 \%$ (47 oocytes) was observed in the medium composed of TCM $+5 \%$ SOF + 5\% FCS + $1 \%$ glutamine $+1 \%$ A.A $+500 \mu$ l antibiotic (Fig.4) .

\section{CONCLUSIONS}

432 mare oocytes were cultivated for 24 hours in three media cultivation;

The highest cultivation rate in three mediums was obatined in TCM-199 medium supplemented with $10 \%$ FCS + 25 mM HEPES + 1 mM sodium pyruvate $+1 \%$ glutamine $+1 \% \mathrm{AA}+10 \mu \mathrm{g} / \mathrm{ml}$ $\mathrm{FSH}+2 \mu \mathrm{g} / \mathrm{ml} \mathrm{LH}+500 \mu \mathrm{l}$ antibiotic 53.33\% (80 oocytes), followed by SOF medium supplemented with $10 \%$ FCS $+1 \%$ glutamine $+1 \%$ AA +500 $\mu \mathrm{l}$ antibiotic, maturation rate was $39.65 \% \quad(58$ oocytes), but the less maturation rate $34.54 \%$ ( 47 oocytes) was observed in the medium composed

Tab. 2 Mare oocytes quality classification after 24 hours of maturation

\begin{tabular}{|c|c|c|c|c|}
\hline In vitro maturation media & $\begin{array}{l}\text { Period of } \\
\text { IVM }\end{array}$ & $\begin{array}{c}\text { Cultivated oocytes } \\
\text { number }\end{array}$ & $\begin{array}{l}\text { Mature } \\
\text { Oocytes }\end{array}$ & $\begin{array}{c}\text { Degenerated } \\
\text { oocytes }\end{array}$ \\
\hline $\begin{array}{l}\text { TCM }+10 \% \text { FCS }+25 \mathrm{mM} \mathrm{HEPES} \\
+1 \mathrm{mM} \text { sodium pyruvate }+1 \% \\
\text { glutamine }+1 \% \mathrm{~A} . \mathrm{A}+10 \mu \mathrm{g} / \mathrm{ml} \mathrm{FSH} \\
+2 \mu \mathrm{g} / \mathrm{ml} \mathrm{LH}+500 \mu \mathrm{l} \text { antibiotic } \\
\end{array}$ & $24 \mathrm{~h}$ & 150 & $\begin{array}{c}80 \\
53.33 \%\end{array}$ & $\begin{array}{c}70 \\
46.67 \%\end{array}$ \\
\hline $\begin{array}{l}\text { SOF }+10 \% \text { FCS }+1 \% \text { glutamine } \\
+1 \% \text { A.A }+500 \mu \mathrm{l} \text { antibiotic }\end{array}$ & $24 \mathrm{~h}$ & 145 & $\begin{array}{c}58 \\
39.65 \% \\
\end{array}$ & $\begin{array}{c}87 \\
60.35 \% \\
\end{array}$ \\
\hline $\begin{array}{c}\mathrm{TCM}+5 \% \mathrm{SOF}+5 \% \mathrm{FCS}+1 \% \text { glutamine } \\
+1 \% \mathrm{~A} \cdot \mathrm{A}+500 \mu \mathrm{l} \text { antibiotic }\end{array}$ & $24 \mathrm{~h}$ & 137 & $\begin{array}{c}47 \\
34.54 \% \\
\end{array}$ & $\begin{array}{c}90 \\
65.46 \% \\
\end{array}$ \\
\hline
\end{tabular}

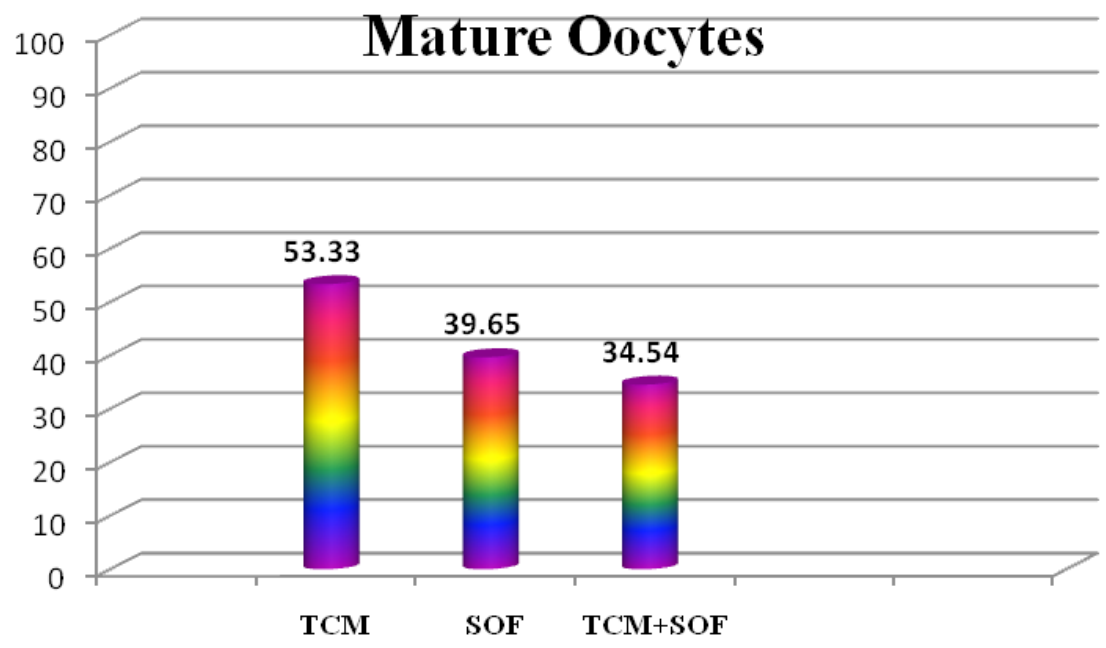

Fig.4. Mature oocytes after in vitro cultivation for $24 \mathrm{~h}$ 
of $\mathrm{TCM}+5 \% \mathrm{SOF}+5 \% \mathrm{FCS}+1 \%$ glutamine $+1 \%$ A.A $+500 \mu$ antibiotic;

Oocytes were selected and classified in two quality categories (mature, degenerated);

We recommend that the extension of the cultivation period from 24 to 28 or 30 hours is necessary to achieve the degree of maturation before in vitro fertilization, and use media supplemented with hormones (FSH and LH), amino acids and synthetic oviduct fluid (SOF).

\section{REFERENCES}

1. Groza I, Hârceaga L., Moise D., Bogdan L., Morar I., Sotoc O., Ciupe simona. (1996). Cercetări privind fecundarea "in vitro" a ovulelor de vacă. Simpozion - Lucrări Ştiinţifice de Medicină Veterinară, Timişoara, p.271;

2. Squires, E.L.(2005). Integration of future biotechnologies into the equine industry. Anim. Reprod. Sci. 89, 187-198; 